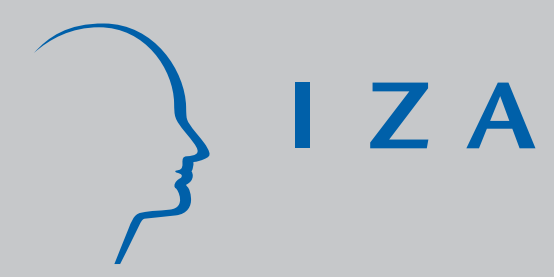

IZA DP No. 161

\title{
Public Employment and Redistributive Politics: Evidence from Russia's Regions
}

Vladimir Gimpelson

Daniel Treisman

Galina Monusova

June 2000 


\title{
Public Employment and Redistributive Politics: Evidence from Russia's Regions
}

\author{
Vladimir Gimpelson, \\ IMEMO, Russian Academy of Sciences and IZA, Bonn \\ Daniel Treisman \\ Department of Political Science, University of California, Los Angeles \\ Galina Monusova \\ IMEMO, Russian Academy of Sciences
}

Discussion Paper No. 161

June 2000

\author{
IZA \\ P.O. Box 7240 \\ D-53072 Bonn \\ Germany \\ Tel.: +49-228-3894-0 \\ Fax: +49-228-3894-210 \\ Email: iza@iza.org
}

This Discussion Paper is issued within the framework of IZA's research area Labor Markets in Transition. Any opinions expressed here are those of the author(s) and not those of the institute. Research disseminated by IZA may include views on policy, but the institute itself takes no institutional policy positions.

The Institute for the Study of Labor (IZA) in Bonn is a local and virtual international research center and a place of communication between science, politics and business. IZA is an independent, nonprofit limited liability company (Gesellschaft mit beschränkter Haftung) supported by the Deutsche Post AG. The center is associated with the University of Bonn and offers a stimulating research environment through its research networks, research support, and visitors and doctoral programs. IZA engages in (i) original and internationally competitive research in all fields of labor economics, (ii) development of policy concepts, and (iii) dissemination of research results and concepts to the interested public. The current research program deals with (1) mobility and flexibility of labor markets, (2) internationalization of labor markets and European integration, (3) the welfare state and labor markets, (4) labor markets in transition, (5) the future of work, (6) project evaluation and (7) general labor economics.

IZA Discussion Papers often represent preliminary work and are circulated to encourage discussion. Citation of such a paper should account for its provisional character. 
IZA Discussion Paper No. 161

June 2000

\section{ABSTRACT \\ Public Employment and Redistributive Politics: Evidence from Russia's Regions*}

Public employment grew surprisingly fast in Russia during the 1990s, at a time when total employment was falling. Most of this growth occurred in the country's 89 regions, and rates varied among them. This paper seeks to explain this variation. Using panel data for 78 regions over 1992-1998 we test several hypotheses. We show that the increase in the share of public employment in total employment has been greatest where unemployment was highest and growing the fastest, in ethnically defined territorial units, and in regions which received larger federal transfers and loans. Regional governors appear to use public employment for several purposes: as a kind of economic insurance to cushion the population against unemployment; as a way of buying votes before elections; and, possibly, as a way of redistributing to minority ethnic groups. Their willingness to use it for any of these is conditioned by the level of federal financial aid they can attract. The paradoxical growth of public employment in Russia appears less a result of ignorant or irresolute central management than a perverse outgrowth of the competitive game of federal politics, in which regional governors use public sector workers as "hostages" to extract transfers.

JEL Classification: $\quad \mathrm{H} 11, \mathrm{H} 51, \mathrm{H} 52, \mathrm{H} 72, \mathrm{H} 77, \mathrm{~J} 45, \mathrm{P} 62$

Keywords: Public employment, redistribution, regional governments, unemployment, transfers, wages, wage arrears, Russia, transition

Vladimir Gimpelson,

IMEMO, Russian Academy of Sciences

23 Profsoyznaya St.

Moscow, 117859

Russia

Tel.: (095) 1283736

Fax: (095) 3107027

Email: vlad@mail.fipc.ru

\footnotetext{
* The authors would like to thank John Earle, Ye. Gontmakher, T. Gorbatcheva, R. Kapeliushnikov, T. Klyachko, H. Lehmann, D. Lippoldt, S. Mizobata, and S. Shishkin for comments and useful conversations. Gimpelson is grateful for financial support to the Thyssen Foundation within the framework of the project "Economic Reform and Labor Market Adjustment in the Russian Federation". Treisman gratefully acknowledges support of the Smith Richardson Foundation, the UCLA Academic Senate, and the UCLA Center for European and Russian Studies.
} 


\section{Introduction}

One of the enduring puzzles of political economy is to explain what determines the size of the public sector. As the economic role of government has expanded dramatically in recent decades in all continents of the world, huge differences have emerged between individual countries. One important aspect of governments' economic activities is their role as employer. In the early 1990s, according to one survey, civilian government employment ranged from just 1.8 percent of the labor force in Senegal to 34.7 percent in Sweden (SchiavoCampo 1997a). Large differences exist even within relatively homogeneous clusters of countries: Sweden's third of the work force in public sector jobs compares to about one twelfth of the workforce in Germany; within Africa, Senegal's 1.8 percent is dwarfed by Botswana's 16.6 percent.

Levels of public employment can also vary widely among regions or municipalities within the same country. In regions of Italy's South, for instance, public employees made up almost one quarter of the work force in 1995. In the country's North, the corresponding figure was only 12 percent (Alesina et al. 1999). Among cities in the US, 8.7 percent of the population of Jackson, Tennessee, were government employees in 1991. The same year, only .05 percent were government employees in Highland, California (Alesina et al., 1998, p.10).

What accounts for variation in public employment across and within nations? A variety of theories have been suggested. The oldest is Wagner's Law — the argument that economic development engenders demands for new types of government services, which require a larger public sector (Wagner 1883). A second view is that public employment is a means by which politicians can conceal redistribution in favor of specific groups. Alesina et al. (1998) argue that for this reason public employment should be greater where income inequality or ethnic diversity is greater. Third, various scholars view government spending as a type of insurance against adverse economic conditions (Cameron 1978), and public employment as one way to buffer the population against private sector unemployment (Rodrik 1997). This argument was developed to explain large public sectors in countries dependent on volatile foreign trade, but its implications are more general. We propose a fourth hypothesis. The views of public employment as redistribution, insurance, or response to modernization all focus on the motives governments might have for hiring public employees. But a necessary condition for them to do so is that governments have the ability to pay them. Thus, the hardness of the budget constraint on governments - itself determined by their ability to collect taxes, attract transfers, or raise loans in capital 
markets—-should also help to explain variation in levels of public employment. ${ }^{1}$

In this paper, we examine which of these theories contribute to explaining the pattern of public employment change in Russia's 89 regions in the 1990s - and with what weights. Studying variation in public employment levels across the regions of a federal country has a number of analytical advantages. First, such a design holds constant (or almost constant) a vast number of potentially confounding factors-from legal system and monetary policy to macro-political culture. Second, the number of subregions or municipalities available for comparison is generally larger than can be mustered for a cross-national study. In focusing on subnational variation in public employment, we follow the recent example of Alesina et al. $(1998,1999)$, and build on a growing literature on the determinants of public policy and public finance at the local level. ${ }^{2}$

For several reasons, Russia offers a particularly promising setting to explore the determinants of public employment. It has a young and relatively fluid, democratizing political system, with electoral checks at local, regional and central levels. Thus, the impact of electoral calculation on policy should be particularly visible. Regions vary quite dramatically in their degree of modernization, facilitating testing of the Wagner hypothesis. ${ }^{3}$ The degree of economic crisis experienced in the 1990s also differed across regions in ways that make possible a test of the hypothesis that public employment acts as social insurance. ${ }^{4}$ Finally, because of the poorly institutionalized system of fiscal federalism, Russia's regional governments face budget constraints of different degrees of hardness. Budget deficits were financed mostly by central fiscal transfers in the 1990s, and the level of these varied considerably across regions. ${ }^{5}$

Russia also exhibits considerable interregional variation in the level of public employment. As of 1998,

\footnotetext{
${ }^{1}$ Wagner also noted the possibility that: "Financial stringency may hamper the expansion of state activities, causing their extent to be conditioned by revenue rather than the other way round," but expressed confidence that "in the long run the desire for development of a progressive people will always overcome these financial difficulties (Wagner 1883, p.8).

${ }^{2}$ See, for instance, Goldin and Katz 1999, Alesina, Baqir and Easterly 1997; for useful reviews, see Rubinfeld 1987; Oates 1994.

${ }^{3}$ As of 1996, regional domestic product per capita ranged from 59.2 million rubles (about $\$ 11,500$ at average market exchange rate) in the oil-and-gas-producing region of Tyumen to 2.8 million (\$545) in the southern republic of Ingushetia. In the city of Moscow that year there was more than one home telephone (or access to one) for each family. In the Nenetsky Autonomous Okrug to the north, fewer than one in four families had access to a home phone. (Statistiscs are from Goskomstat, Rossiisky statistichesky yezhegodnik, 1998.)

${ }^{4}$ In the average region, real industrial output dropped by about 57 percent between 1990 and 1996. But while in some regions it fell by more than 80 percent (Yevreskaya AO, Aginsky-Buryatsky AO, Dagestan), in others it dropped by less than 30 percent (Yamalo-Nenetsky AO, Sakha, Nenetsky AO, Khakassia). See Freinkman et al. 1999.

${ }^{5}$ For analysis of the determinants of central transfers, see Treisman $(1996,1998,1999)$.
} 
the level of public employment in Russia's regions ranged from 19.5 percent in Tyumen Oblast to 54 percent in Ingushetia. ${ }^{6}$ Most of the country's public sector job creation in the 1990 s appears to have occurred in establishments that are subordinated to regional administrations and funded from regional budgets. Thus, the public employment figures can reasonably be thought to reflect particular regional policies and constraints.

Russia's experience in the 1990s offers additional puzzles for the political economist. The decade saw a massive, rapid process of privatization, reflecting in part deliberate policy and in part a severe collapse in state revenues. Employment in state owned enterprises fell from more than four fifths of total employment in 1990 to little more than one third in 1998. At the same time, total employment dropped by 12 percent and employment in the category "large and medium-sized enterprises and organizations," which includes all public employment, fell by 27.5 percent. However, contrary to all expectations, employment in public administration and in the almost entirely public education and health care sectors grew. That in education, culture and art grew only in relative terms-from 9.6 percent of the total in 1990 to 11.2 percent in 1998. But the actual number of employees went up in healthcare, sport and social protection (an additional 215 thousand workers) and in public administration (an additional 1.2 million)! Observers had expected that: "wages-and consequently employment-in health and education would fall relative to wages in the rest of economy as the market sector expanded." " Some decline was seen as appropriate because employment in these sectors started out from a comparatively high base-teacher-student ratios and other indicators of public service provision were often higher than in industrial countries. ${ }^{8}$ In most other CEE transition countries health and education have downsized, while only employment in public administration has grown. The change in Russia's health and education sectors — expanding relative staffing levels alongside falling wages—stands out as a puzzle to be explained.

Second, while employment in government administration at the federal level has fallen in Russia since the beginning of transition, the corresponding statistic at the regional level has risen. ${ }^{9}$ A similar trend has been

\footnotetext{
${ }^{6}$ This represents the share of education, culture, art, and science; health care and sport; social protection; and public administration in total employment. For discussion of alternative definitions of public employment, see below.

${ }^{7}$ Cheasty and Davis (1996).

${ }^{8}$ Ibid.

${ }^{9}$ Data on employment in central branches of federal government executive bodies are available only from 1994. These show a fall in central federal government employees from 33.9 thousand in September 1994 to 28.9 thousand in December 1998 (Rossiisky Statistichesky Yezhegodnik 1999). Before this, data are only available for public administration within the city of Moscow (i.e. including both federal government and Moscow city government). This category of workers fell in absolute terms from 183 thousand workers in 1992 to 135 thousand in 1994. It is extremely likely that this contains a drop in federal employees. Employment in public administration in regions other than Moscow grew by about 1.25 million workers between 1992 and 1998 .
} 
noted in other parts of the world. Schiavo-Campo and colleagues find that in the 1980s and early 1990s local and regional employment in government administration rose in Asia, Latin America, and the OECD, while central government employment fell. Understanding the reasons for such a shift is crucial in order to assess its implications for the quality of public good provision and the desirability of decentralization reforms. It might represent an efficiency-enhancing decentralization of the provision of public services (au Oates 1972), making possible a closer match between community demands and the mix of public goods provided. Perhaps part of the increase represents the creation of infrastructure necessary for a law-governed market economy—unemployment assistance offices, antimonopoly structures, agencies dealing with bankruptcy, and so forth. Or it might represent the exploitation by local and regional politicians of rent-seeking opportunities opened up by central government attempts at liberalization. As financial resources are shifted down the state pyramid, are they used more efficiently to provide public goods? ${ }^{10}$ Or are they invested at higher rates into patronage and bribes? Russia presents a revealing case study of such decentralization.

In the next section, we discuss hypotheses derived from the literature on public sector growth. Then, in Section III, we describe the data and definitions of key variables. Section IV shows the general pattern of public employment in Russia's regions. Section V presents a multivariate analaysis of this pattern. Finally, Section VI concludes with a discussion of the results.

\section{Hypotheses: What Explains Regional Levels of Public Employment?}

We have six basic hypotheses. Though we discuss them separately, we do not consider them to be in contradiction and some are in fact highly complementary. The empirical analysis attempts, therefore, to estimate the weight of each in determining public employment levels in the Russian regions. Since the period we consider is one of transition from policy-making under communist rule to that under a market economy with elected governments, we expect many of the factors to become more important over time.

\section{Economic Development}

For decades, economists believed that the public sector grows according to Wagner's "law of increasing expansion of public, and particularly state, activities" (Wagner 1883, p.8). Over time, public spending as a proportion of national income tended to grow, Wagner observed, "in progressive countries, at least in our Western European civilization". Interestingly for present purposes, he suggested that the association of economic

\footnotetext{
${ }^{10}$ The economics literature, from Tiebout (1956) on, provides various reasons to expect that this would be the case. In a recent paper, Qian and Roland (1998) model how Tieboutian competition between subnational
} 
development and state expansion should hold even more strongly "when administration is decentralized and local government well organized," and noted a "marked increase in Germany in the fiscal requirements of municipalities, especially urban ones" (Ibid).

Wagner was somewhat vague about the cause of state expansion in more developed economies, attributing it to "the pressure for social progress", which required a deeper state involvement in the economy. Others have added flesh to the idea. Musgrave suggested that in affluent societies, a growing share of private consumption expenditures "flows into 'adult toys' for leisure time use... pleasure cars, motorboats and other durables" the operation of which requires public investment and services - the building of "high-speed roads, marinas, parks, and so forth" or the organization of "traffic patrols, park services, or weather reporting" (Musgrave 1969, p.79). The result should be an increase in the population's willingness to pay for public investments and employment-increasing services. As population density rises with urbanization, the risks of crime or accident may also rise at a disproportionate rate, requiring greater proportional public spending on policemen, firemen, and health inspectors to achieve the same level of public safety.

The cross-national evidence on Wagner's Law is generally clear and supportive. The association between economic development and larger government is obvious from merely glancing through the statistics on countries' spending levels. An examination of long periods of history in almost any country suggests that GDP and the size of government have grown in tandem (though not always at the same rates). There also seems to be a clear positive relationship between national income and public employment. Schiavo-Campo et al. (1997a, p.viii) find a close and significant positive relationship between relative government employment and national income (see also Heller and Tait 1984). They do not observe a clear association between income and public employment among the OECD countries taken separately (in this small-n estimation of data for the early 1990s), but using a different dataset on public employment in 1963-83, Cusack, Notermans and Rein (1989) do. Kraay and Van Rijckeghem (1995) find that government employment increases with urbanization and education levels.

Do the same arguments that predict a link between higher income or development and higher public employment also make sense at subnational levels? As already noted, Wagner clearly thought they should. German urban municipalities were in his time showing expanded "fiscal requirements," which he attributed to a growing demand for public goods and services associated with social progress. The public services needed to deal with problems of urban congestion or to facilitate the enjoyment of Musgrave's 'adult toys' - e.g. lifeguards, traffic police, highways - can mostly be provided at least as efficiently at the local or state as at the central level. Alesina et al. (1998), report a generally positive though often insignificant coefficient on per capita

governments might harden their budget constraints and reduce their waste or theft of resources. 
income in their regressions of government employment in American cities. This motivates our first hypothesis.

H1: public employment will be higher (and will grow faster in the transition period) in more economically developed or urbanized regions.

\section{The Politics of Redistribution}

Alesina and colleagues (1998) argue that spending on public employment, though promoted as necessary to provide public goods or services favored by the majority, is often little more than a means of channeling patronage to minority groups. By disguising aid as public good provision, politicians are able to redistribute income to particular constituencies in ways that circumvent opposition to explicit tax-transfer schemes. "[W]hile an explicit and more efficient redistributive scheme would be politically opposed, a less efficient system based upon inflated government bureaucracies may find political support." The implication is that where minority groups are relatively stronger - in their operationalization, where income inequality or ethnic diversity are greater-such redistributionally-motivated public employment should be higher. They present strong statistical evidence that this is indeed the case among U.S. cities. One might expect such inequality or ethnic diversity to have similar effects in Russia. ${ }^{11}$

H2: public employment will be higher (and will grow faster in the transition period) in regions with greater income inequality or ethnic diversity.

Unfortunately, we did not believe that the Russian data available on income inequality within regions were adequate to test this part of the hypothesis, so we limited ourselves to testing whether ethnic republics within Russia had different trajectories of public employment. Focusing on the ethnic status of regions is an extremely preliminary way of getting at the ethnic redistribution hypothesis, and-as we discuss in the analysis - there are other possible interpretations of results involving the ethnic region variable. In particular, regions in our sample which had an ethnic identity also had a distinct administrative status - that of republics or autonomous districts. Higher administrative status is likely to be used to justify and to help to finance larger bureaucracies. So, as we will discuss below, disentangling specifically ethnic effects from those associated with institutional status is difficult.

\footnotetext{
${ }^{11}$ There are two theoretical questions that remain open, however. First, Alesina et al. do not model why an incumbent politician would want to provide benefits to a minority against the wishes of the majority, whose votes are needed to stay in office. The propensity to favor the minority is introduced as an exogenous parameter. This can, of course, be motivated as the result of ethnic socialization, feelings of altruism, or conceptions of fairness. Second, it is not obvious why, given such a propensity, the extent of hidden redistribution would correlate with the size of the minority group. The implicit assumption seems to be that policymakers want to provide public jobs to some fixed proportion of members of the favored minority group. Why they would do this rather than maximizing the number of public jobs provided to the group subject to some constraint is not clear.
} 


\section{Public Employment and Electoral Competition}

Incumbent politicians may not just use public employment to disguise transfers to minorities that their supporters would not approve; they may also use it to coopt the voters needed to form supportive majorities. A copious literature explores ways in which incumbent politicians manipulate public policies to buy votes, especially around the time of elections. ${ }^{12}$ Russia underwent a democratic revolution in the 1990s, with the first competitive elections held in 1989 and 1990 (for the Soviet and Russian central legislatures and for Russian regional legislatures), and relatively free elections held in 1993, 1995 and 1999 (for the central parliament) and 1996 and 2000 (for the presidency). Elections for regional governors were held gradually in an increasing number of ethnic republics and non-ethnic regions from 1991 to 1995-and then in a wave of elections in 19967 that left almost all 89 regions with popularly elected executives. Theories of the "opportunistic" political business cycle posit that incumbent politicians expand public spending in the run-up to elections in order to buy the good will of voters (Nordhaus 1975). One way in which they can attract voters is by creating additional public jobs. Since most of the benefit of these jobs to the new employee will come in the form of wages paid after the election, this creates an incentive to vote the "right" way.

This reasoning suggests one way in which public employment levels might be expected to vary with the electoral cycle. One might expect public employment to increase in the year before an election, and to decrease in the year after as the political urgency declines and the need for fiscal stringency increases — or as a new incumbent sweeps the deck of his rival's political appointees. The federal division of responsibility for public employment in Russia implies that one might expect to see such effects associated with both central and regional executive elections. For such pre-election increases to be feasible, incumbents must know in advance that an election is coming.

H3: a) public employment nationwide will grow faster than the trend in the year before an (expected) central presidential election (and perhaps also in the election year itself), and slower than the trend in the year after;

b) public employment in a given region will grow faster than the trend in the year before an (expected) gubernatorial election in that region (and perhaps also in the election year itself), and slower than the trend in the year after.

\footnotetext{
${ }^{12}$ For a review, see Alesina, Roubini and Cohen (1997).
} 


\section{Political Ideology of Leaders}

In the press, differences in the scale of public employment are most often attributed to ideological differences between the policy-makers responsible. Sweden's public sector is seen as having grown in the 1970s because of the social democratic views of those in government. The general fall in government employment in the OECD in the 1980s is attributed to the Reagan-Thatcher revolution. Various scholars have also traced distinctive economic policies to particular party governments (Hibbs 1977, Cameron 1978). Among Russia's regions in the 1990s, governors differed markedly in both ideological convictions and party affiliations. At one end of the spectrum was the staunchly left-wing Yuri Goryachev of Ulyanovsk Oblast, who attempted to keep inflation down and real incomes high by imposing price limits far longer than in most other regions. At the other were such market reformers as Boris Nemtsov of Nizhny Novgorod or Konstantin Titov of Samara. The degree to which regional governments liberalized by cutting their workforces might reflect such differences of governor ideology.

H4: public employment will be higher in regions where the governor is affiliated with the communists.

\section{Public Employment as Economic Insurance}

Another function of public employment may be to cushion the impact of macroeconomic crises caused by terms-of-trade shocks or other adverse events. ${ }^{13}$ Rather than redistribution, the motive behind "excess" public employment is social insurance. "By providing a large number of 'secure' jobs in the public sector, a government can counteract the income and consumption risk faced by the households in the economy" (Rodrik 1997, p. 3).

A couple of questions are left unresolved. First, it is not immediately clear why insurance could not be provided privately to reduce such risk or (more efficiently) by government on a fee-for-service basis. Rodrik refers to "undiversifiable external risk faced by the domestic economy," but does not say why such risk is undiversifiable. In the context of Russia's transition, though, it is easy to see why such insurance demand might not be met by nascent markets. Second, it does not seem likely a priori that those hired to fill government jobs would generally be those left unemployed by terms-of-trade shocks- the out-of-work textile worker does not usually turn up the next month as civil servant or teacher. Rodrik suggests that benefits may be passed on to the

\footnotetext{
${ }^{13}$ See Rodrik (1997), Agenor (1996). Rodrik examined the impact of exposure to external trade. But, especially in a study comparing regions within the same country, some other indicator of vulnerability to external shocks may be appropriate.
} 
needy via the networks of extended families, but this is also somewhat tenuous. Either the redistribution or the demand for public goods arguments may still be needed to explain who gets hired.

Bearing in mind that the insurance argument may actually be complementary to the previous hypotheses, and that some questions would need to be answered to make it fully plausible, we nevertheless seek to test the hypothesis that the government is the "employer of last resort," using public employment to cushion against external shocks.

H5: public employment will be higher (or faster growing) where unemployment is greater, or rises particularly fast.

\section{Public Employment and Soft Budget Constraints}

Whatever the motives of policymakers, their ability to maintain large public sectors will depend on their financial resources. When regional governments receive larger transfers from federal government, this increases their capacity to fund public employees. Freinkman and Haney (1997) show that subsidies to inefficient enterprises increased in Russia's regions as transfers from the central budget increased. It is possible that another part of such transfers went into hiring (or deferring layoffs) of public employees. Variation across regions in the level of public employment may reflect differences in access to such transfers rather than (or as well as) differences in the degree of demand for public services, redistribution, or social insurance.

H6: public employment will be higher (or faster growing) in regions that received larger (or increasing) transfers from the central budget.

\section{Definitions and Data}

There is no universal and generally accepted definition of what is called public employment. ${ }^{14}$ The 1997 World Bank study defines public employment as that in central and non-central administration, public health and education. ${ }^{15}$ In a similar vein, we use a measure $\left(\mathrm{PE}_{\mathrm{t}}\right)$ that represents the share of total employment in education, health care and sport, social protection, culture, art and science, and public administration. Some adopt a broader definition, including all employees of state or municipally owned enterprises. In future work, as data permit, we will test the results obtained using $\mathrm{PE}_{\mathrm{t}}$ against results when more inclusive dependent variables are used.

The measure $\mathrm{PE}_{\mathrm{t}}$ has weaknesses that need to be acknowledged. It does not separate regional government establishments from those under federal subordination, and so also includes enterprises and

\footnotetext{
${ }^{14}$ See, e.g., Rose (1985) and Schiavo-Campo (1997b).

${ }^{15}$ Schiavo-Campo et al. (1997b), p.47.
} 
organizations that are located in the relevant region but funded from Moscow. The federal/regional division of fiscal responsibilities varies between subdivisions of the public sector and has changed over time. Regional budgets went from financing 66 percent of consolidated budget education spending in 1992 to 86 percent in 1996. The regional share of spending on social protection grew in the same period from 28 to 69 percent; that on health and sport from 89 to 90 percent; and that on state administration from 60 to 69 percent. ${ }^{16}$ The changing framework of fiscal federalism needs to be borne in mind in interpreting the results. Another possible problem is that $\mathrm{PE}_{\mathrm{t}}$ embraces sectors that are predominantly public but may, however, include some private entities (in education, health care, culture or research). The private sector share in these sectors is small, and most of the institutions in them are managed and funded by regional authorities. The largest cities, Moscow and St. Petersburg (both of which we refer to as capitals), are clear exceptions - most of the country's privately run health care and education are concentrated in them. These cities also contain most of the federal public employment financed directly from the federal budget (for instance, that in federal ministries, major universities, theaters, libraries, hospitals, and research centers.) We therefore try controlling for the capital cities in our multivariate regressions. $\mathrm{PE}_{\mathrm{t}}$ is available for 1992 to 1998.

To capture the six key hypotheses and control for possible confounding factors, we used data from a number of sources. For unemployment, we use the regional rates reported by Goskomstat RF using the OECD/ILO definition. Per capita gross regional product, the urban share of the population, the shares of the population under 16 and over 55 also came from Goskomstat publications. To focus on the initial level of economic development and reduce problems of endogeneity, we used gross regional product for the first year available, 1994. Data on transfers and loans to the regions are from Ministry of Finance reports on budget execution, for 1992-96 presented in Freinkman et al. (1999), and for 1997 obtained directly from the Ministry of Finance. The transfers-plus-loans variables measure federal transfers and loans to the region per capita in thousand December 1991 rubles, deflated with the regional CPI's calculated by Goskomstat. The data on gubernatorial elections in the regions and on the political affiliations of the governors were gathered from a number of sources, including McFaul and Petrov (1998), McFaul, Petrov, and Ryabov (1999), and the Institute for East-West Studies Handbook of Regional Executives. In testing for pre-election increases in public employment, we excluded those elections which could not have been predicted by the incumbent the year before (for instance, those that were called just a few months before the election).

\footnotetext{
${ }^{16}$ Figures for education, social protection, and health and sport are from Freinkman et al. (1999, Table A10). The 1992 figure for administration is calculated from figures in Sinelnikov (1995, Table 5.1), which gives figures of 42 and 64 billion rubles for state administration spending of federal and subnational budgets respectively. The 1996 figure is from Rossiisky Statistichesky Yezhegodnik 1999, p.492.
} 


\section{General Trends in Public Employment}

In Russia in the 1990s, a combination of economic reforms, drastic GDP contraction, and growth in the underground economy led to a sharp fall in total registered employment. Whereas in 1992, more than 72 million Russians were officially employed, by 1998 the total had dropped to less than 64 million (see Table 1). This represented a decline from 95 percent of the labor force ("economically active population") to 88 percent. The state sector was no exception to this trend. As privatization and new private business development began to reshape the post-communist economy, employment in state-owned enterprises and organizations fell even faster. State sector employees declined from about 83 percent of the total in 1990 to 38 percent in 1998.

\section{[Table 1 About Here]}

However, if we look more specifically at sectors made up of public service providers funded directly from the budget—-health care and sport, social protection, education, culture and art, science, and public administration, i.e., the subsectors we include in $\mathrm{PE}_{t}-$ the share of such public service providers has grown in the aggregate (Table 2). Employment in public administration grew from 2.1 percent of the total in 1990 to 4.4 percent in 1998; that in healthcare, sport, and social security grew from 5.6 to 7.0 percent; and that in education, culture and art from 9.6 to 11.2 percent. The workforce in science fell sharply, but not by enough to offset the large gains in other categories: overall employment in these overwhelmingly public sectors rose from 21.0 to 24.6 percent of the total. Employment in health care, sport and social protection and in public administration did not only increase in relative terms as total employment dropped-the actual number of employees in these sectors increased. In absolute terms, the workforce in public administration grew by 1.2 million, and that in health, sport and social security by 215 thousand.

[Table 2 About Here]

Public employment levels vary significantly across regions. The share of education, culture, art, science, health care, sport, social protection and administration, $\left(\mathrm{PE}_{\mathrm{t}}\right)$, ranged from 19.5 percent of total employment in 1998 in Tyumen Oblast to 54 percent in the republic of Ingushetia. Regions differed not just at a particular point in time but also in the rate and direction of change. Table 3 shows that the mean has been growing while the 
variation remains fairly large. While the vast majority of regions increased their level of public employment, a few decreased theirs. Chart 1 depicts how $\mathrm{PE}_{\mathrm{t}}$ changed in particular regions between 1992 and 1998. Most of the regions lie above the no-change line, indicating a rise in PE. The handful of regions that bucked the trend and actually cut public employment are led by Moscow city and St Petersburg.

[Table 3 and Chart 1 About Here]

How do the high public employment regions differ from the low public employment ones? To get a preliminary sense of this, we examined the ten regions with the highest public employment as of 1998 and compared them to the 10 regions with the lowest public employment. Most of the regions with the largest share are ethnically-defined units with autonomous status. They are mostly poor and heavily subsidized but enjoy relatively more administrative power than regions lacking autonomous status. Chita, Pskov, and Novgorod Oblasts round out the list. The lowest rates of public employment occur mostly among heavily industrialized regions, along with the capital cities of Moscow and St Petersburg. To test for the relative contribution of our six hypotheses, we now proceed to multivariate analysis.

\section{Multivariate Analysis}

To disentangle the effects of different possible causes, we regressed our indicator of public employment, $\mathrm{PE}_{\mathrm{t}}$, on explanatory variables related to our hypotheses. We used a cross-section, time series design to exploit both the cross-sectional and intertemporal variation in the data. We calculate coefficients by OLS, but report "panel-corrected standard errors", as recommended by Beck and Katz (1995), which are corrected for panel heteroskedasticity and contemporaneous correlation. ${ }^{17}$ To reduce problems of autocorrelation, we included a lagged term of the dependent variable, as recommended by Beck and Katz (1996), who argue that this is preferable to using generalized least squares or other available techniques. The results should therefore be interpreted as explaining change in public employment shares rather than their absolute level. We also included dummies for year in the regressions, to separate general trends from patterns associated with particular regions.

Table 4 shows the results of these regressions. We first look for a simple correlation between the given independent variable and public employment, controlling only for year and previous year public employment. Then, in the model shown in column 9, we include the full range of relevant explanatory variables, along with

\footnotetext{
${ }^{17}$ Panel-corrected standard errors are more accurate than standard errors computed by the Parks FGLS method for data of the kind analyzed in this paper (see Beck and Katz 1995). In STATA, we used the option pcse.
} 
controls for the age structure of the population (which may capture differences in regions' demand for public services such as health care or education), and for Moscow and St Petersburg (in which the relevant sectors include some significant federal public component and private element). ${ }^{18}$ Relatively quickly-changing variables such as unemployment or central transfers are included in the form of the previous year's level and the one-year change to make it possible to capture effects of both recent changes and longer run trends. In Table 5, we show the full model when run for different sectors separately.

[Tables 4 and 5 About Here]

A number of results emerge from Tables 4 and 5. First, Wagner's law does not help to explain interregional variation in public employment in Russia. On the contrary, there is a negative correlation between development (measured either by per capita gross regional product or urbanization) and public employment (though this drops to insignificance if the other explanatory variables and controls are included). If Wagner was right that economic development increases demand for public services, this does not seem to be what is driving changes in the pattern of public employment in 1990s Russia. Second, public employment growth was faster in ethnically-defined subunits of the Russian state. Most of the effect reflects the younger age-structure characteristic of such ethnic republics and districts. On average in the ethnic regions, almost 28 percent of the population was aged under 16, compared to 22 percent in the non-ethnic regions. Controlling for the proportion under 16 by itself caused the estimated coefficient on ethnic status to drop from .84 to .39 . A younger population should boost the demand for education, and ethnic status was significantly associated with higher employment in this sector but not with higher employment in administration or health. ${ }^{19}$ But although most of the "ethnic" effect looks more like meeting demand than political redistribution, a significant residual effect does remain even once all controls are included, suggesting that ethnic units have on average almost one third of a percentage point higher public employment that is not explained by the population's age structure.

Does this reflect pressures for ethnic redistribution? Obviously, more direct information would be needed to establish this - for instance, data on the ethnic composition of public employment in the regions, data

\footnotetext{
${ }^{18}$ The results are not changed if we leave the capital cities variable out. In including the age structure controls, we follow previous studies such as Alesina et al. (1998).

${ }^{19}$ We tried running regressions like those in Table 5 but dropping the age variables. Ethnic status was highly significant in the regression for employment in education, but not in those for employment in healthcare or administration.
} 
that unfortunately were not available. And there are other possible explanations. As noted already, the ethnic regions have a different administrative status and political relationship with the center which affords them greater rights and privileges than their non-ethnic counterparts. Here we can only present some additional indirect evidence. If public employment in ethnic regions was higher because of redistribution to non-Russian ethnic groups, the pressures for this might be greater if the non-Russian population in the region was larger. ${ }^{20} \mathrm{We}$ tried including a term for the proportion of the population in the ethnic regions that was non-Russian (as of the 1989 census) in the full model regression. In fact, the proportion non-Russian was negatively (but not significantly) related to the change in public employment. This might cast some doubt on the interpretation of the finding as evidence for ethnically motivated redistribution. However, another piece of evidence is slightly more supportive. Controlling for the status of the ethnic unit, if the unit had a governor (for at least part of the year) who was of non-Russian nationality, the increase in public employment tended to be almost one third of a percentage point higher (though this was only significant at about $\mathrm{p}<.20$, and so should not be viewed as at all reliable). Our preference is to remain agnostic about whether the faster growth of public employment in Russia's ethnic units is the result of redistribution to non-Russian groups or is better explained as a result of the distinct administrative status of ethnic regions.

The evidence on electoral effects is mixed. At the national level, Russia held a presidential election in 1996. The trend of public employment growth shown in Table 2 fits the predictions of the electoral cycle hypothesis perfectly. The public employment share grew by one percentage point in 1995, by 1.2 percentage points in the election year, and then fell by .1 percentage point in 1997. In absolute terms, public employment increased by 201 thousand jobs in 1995, by 670 thousand in the election year, and then fell by 445 thousand in the year after. Examination of the year dummies in Table 4 suggests that this pattern held not only in the aggregate but on average across regions. The estimated effects (from model 9) were for a 1.17 point increase in public employment in 1995, a 1.64 point increase in 1996, and a .35 point drop (not significant) in 1997. The evidence is hardly conclusive - many other factors might explain why such a trend appeared in these years. Note, however, that such a pattern is not explained away by the other factors hypothesized to affect public employment and included in the regressions. Table 5 shows that this trend is entirely caused by changes in the level of employment in public administration - both health and education employment do not have this trend in the estimated year effects. Recall that public administration was the category of public employment that actually rose not just as a share of total employment but as the number of jobs positively increased.

\footnotetext{
${ }^{20}$ At least, that is the argument in Alesina et al. (1998), though note our uncertainty about the logic behind this in footnote 11 .
} 
Evidence of cycles in public employment around elections for regional governors are far less clear. The pattern appears to fit the hypothesis when no controls are included - there is then a significant increase in public employment during the year in which the region held a gubernatorial election (Table 4, columns 4 and 5). However, this effect disappears completely in the aggregate regressions once controls are included (column 9). A significant effect remains, however, in the regression for public administration employment (Table 5, column 3), which increases significantly in the year before a gubernatorial election and falls significantly in the year after. Are new, non-incumbent governors more likely to sweep out the Augean stables after election, firing the political appointees of their predecessors? The signs of the coefficients on the variable for a non-incumbent elected the previous year fit this conjecture, but the estimates are not significant except in the regression for education, culture, art and science employment in Table 5. (And, for public administration employment, there is no greater propensity for a new governor to reduce employment after the election.)

To sum up, there is some quite persuasive evidence of political business cycle manipulations in the levels of employment in public administration, but not in those of education or healthcare. ${ }^{21}$ Public administration employment in the average region rose before the 1996 nationwide presidential election and fell afterward (in ways that cannot be explained for instance by changes in unemployment levels). Public administration employment also rose significantly faster in the year before an expected gubernatorial election and fell significantly faster in the year after the election. There is some relatively weak evidence that newly elected governors reduce public employment—at least in education, culture, art and science — faster than if the incumbent is reelected.

One interesting negative result emerges from the analysis: the political ideology or affiliations of the governor do not appear to influence his public employment strategy. Governors affiliated with the communists were no faster or slower than others to increase the level of public employment, either in the aggregate or taking different types of public employment separately.

The economic insurance hypothesis was quite strongly supported. In regions with higher unemployment rates and especially in those that had suffered a particularly sharp increase in unemployment that year, public employment increased significantly. A one percentage point jump in unemployment in a given year was associated with a .09 percentage point increase in public employment, other things equal. ${ }^{22}$ Most of the increase came in education, culture, art, science, healthcare, sport and social protection, but a small part may also have

\footnotetext{
${ }^{21}$ For an argument that one should not expect to see political business cycle patterns in all indicators in all elections, see Treisman and Gimpelson (2000).

${ }^{22}$ This is based on the estimates of the model in column 9, with controls and indicators for other hypotheses
} 
come in public administration (see Table 5). Thus, the evidence does support the conjecture that regional governments in Russia act as "employers of last resort", trying to cushion the blow of sharp increases in local unemployment. Their ability to do so is obviously limited, as suggested by the low estimated coefficient.

Finally, the government budget constraint hypothesis was strongly supported by the evidence. Regions receiving higher or more rapidly increasing financial aid from the federal government had faster growing public sectors. The estimates in Table 4 are remarkably stable whether or not controls and indicators for other hypotheses are included. For every additional thousand December 1991 rubles per inhabitant a region received in a given year in federal transfers and loans, public employment increased by about .6 of a percentage point. For instance, Archangelsk Oblast had the median increase in transfers and loans in 1997-about 53 December 1991 rubles per capita. Had its transfers and loans increased as much as in the Evenk Autonomous Okrug (by 1,332 rubles per capita), the regression predicts that its public employment level would have been about .8 of a percentage point higher. Table 5 suggests that increases in transfers and loans translated within a year into higher employment levels in education, culture, art or science, but that higher federal aid led with a longer lag to higher staffing levels in healthcare, sport, social protection, and public administration as well.

Are regional governments more likely to spend money received in transfers and loans from the federal government on increasing public employment than they are to spend other kinds of locally raised revenues on this? The data suggest that the answer is yes. When terms for the region's real revenues from other sources and change in the region's real revenues from other sources are included in the regressions-either with or without controls and other variables - the estimated positive effects of transfers and loans remain highly significant with similar coefficients, but the coefficients on both previous year other revenue and change in other revenue are negative (not significant if controls are included). That is, other things equal, regional governments with higher or faster increasing other revenues do not have faster growing public employment. It is only federal transfers that appear to stimulate this public sector expansion.

To recap, contrary to Wagner, it was less developed regions that had the greatest increases in public employment after transition to the market in Russia. Ethnically defined units of the state also had larger increases, especially in education, culture, art and science, which might suggest ethnically motivated redistribution, but might equally well reflect different demand for and supply of public employment in regions with different administrative status. The political ideology or affiliation of regional governors does not seem to affect their public employment strategies. There was some evidence of opportunistic increases in public administration employment before elections (and reductions afterward). Public employment correlated positively

included. 
with the trend and recent changes in unemployment, and was strongly related to the level and recent change in federal transfers and loans - though not to the level or change in locally raised revenues.

\section{Discussion}

Public employment in Russia's regions increased more when federal transfers and loans increased. But what caused what? It might be that increased transfers make possible increased public sector hiring (or slower firing), the interpretation we have assumed. But higher levels of public employment might themselves call forth larger federal transfers.

We lacked a sufficiently long time sequence of data to run reliable Granger tests of causality. However, we did run panel regressions trying alternately to predict PE with lagged transfers and loans and transfers and loans with lagged PE. ${ }^{23}$ Lagged transfers and loans turn out to be extremely significant (at $\mathrm{p}<.001$ ) predictors of PE, controlling for lagged PE and year dummies. When the full period 1992-98 is included, lagged PE is not at all significant in predicting transfers and loans. However, lagged PE became a better predictor of transfers and loans as the decade progressed. It is only in 1992-94 that PE is insignificant; if a similar regression is run using just the data from 1995 on, lagged PE is even more significant at predicting transfers and loans than vice versa. Our interpretation is that: (a) transfers and loans help to predict public employment in the whole period 1992-98, and (b) higher public employment helps to predict faster rising transfers and loans in the period from $1995 \mathrm{on}$.

In fact, observation of political events and discourse suggests the possibility of a perverse interaction between public employment and federal transfers in the late 1990s. Governors may have consciously chosen to boost (or slow decline in) local education, health, and administrative payrolls in the hope of attracting greater federal financial aid. By hiring more doctors, teachers, and the like—or not laying off those for which long-term financing was unavailable - regional politicians used the federal transfers received in a given year to create hostages who could help to pressure the federal government for transfers in the future. Higher transfers made this hiring possible, but probably left a good deal of the total for governors to divert to other uses. ${ }^{24}$

While we cannot prove all aspects of this story, a variety of evidence supports it. First, the surprising growth in the public employment share in the 1990s was clearly masterminded by regional governors more than by central officials. Education and health had been almost entirely devolved to regional and local governments,

\footnotetext{
${ }^{23}$ The regressions were of the form: (1) $\mathrm{pe}_{\mathrm{t}}=\mathrm{a}+\mathrm{b}_{1} \mathrm{pe}_{\mathrm{t}-1}+\mathrm{b}_{2} \operatorname{trans}_{\mathrm{t}-1}+\mathbf{b}_{3} \mathbf{d}$, and (2) $\operatorname{trans}_{\mathrm{t}}=\mathrm{a}+\mathrm{b}_{1} \mathrm{pe}_{\mathrm{t}-1}+\mathrm{b}_{2} \operatorname{trans}_{\mathrm{t}}$. ${ }_{1}+\mathbf{b}_{3} \mathbf{d}$, where trans $\equiv$ federal transfers and loans; $\mathbf{d}$ is a vector of year dummies; and $\mathbf{b}_{\mathbf{3}}$ is a vector of coefficients on the year dummies.

${ }^{24}$ Freinkman and Haney (1997) find that higher federal transfers correlated during this period with higher spending on housing and heating subsidies - a form of spending that is particularly regressive, since the larger houses and apartments of the rich use more subsidized heat.
} 
so hiring decisions in these fields were made at these levels. The number of executive branch workers in Russia (rabotniki organov ispolnitelnoi vlasti i mestnogo samoupravlenia) increased by 90,000 between 1994 - the first year for which Goskomstat provides figures-and 1998. This represented a fall of 5,000 in federal officials based in Moscow, an increase of 35,000 in federal officials based in the regions, and an increase of 60,000 in regional and local officials. ${ }^{25}$ (In other words, federal executive branch employees in Moscow and the regions grew by 30,000 between 1994 and 1998, while regional and local executive employees grew twice as fast.) As of 1999, there were more officials of the Moscow city government working in Moscow than there were officials of the federal government (20,163 including local government subdivisions, compared to 13,854)! $!^{26}$ Employment in public administration in regions other than Moscow grew by about 1.25 million workers between 1992 and 1998 . Some of the increase may have been in regional branches of federal government bodies-but probably only a small part.

Second, as already noted, higher public employment from 1995 on did correlate with higher federal transfers and loans the next year. A far more comprehensive analysis would be necessary to test such a correlation for robustness, but it is at least consistent with the story told above. One reason for this channeling of federal financial aid to regions with high public employment may have been the mounting wage arrears in the public sector. Overdue wages in healthcare grew from 823 billion rubles at the end of 1995 to 3,563 billion at the end of 1998 (though they dropped a little in 1997). Those in education grew from 1,398 billion to 5,582 billion. ${ }^{27}$ Both of these rates were faster than the average for the economy. Regions with higher wage arrears tended to have higher votes for the political opposition in the 1993 parliamentary election and lower votes for Yeltsin in the 1996 presidential election (Treisman 1999, chapter 4). Also, regions with higher public sector wage arrears may have been more prone to disruptive strikes. In fact, as Table 6 shows, by 1997 strikes in Russia occurred almost entirely in the education sector. ${ }^{28}$ In 1998,95 percent of the organizations where strikes occurred were in education; and the education sector lost 66 percent of the total time lost to strikes (see Table 6). The extent of wage arrears in education in a given region as of the end of 1997 (as a percentage of the monthly wage bill) correlated at .39 with the number of man-days lost to strikes per thousand employees in the region that year.

\footnotetext{
${ }^{25}$ Trud I Zanyatost v Rossii 1999, p.96.

${ }^{26}$ Ibid, p. 98 .

${ }^{27}$ Ibid, p.345.

${ }^{28}$ The healthcare sector also has a very high propensity for collective protest, which was partly neutralized by strong moral pressures on medical personnel not to strike and public outrage when fatalities could be linked to strikes. Nevertheless, cases of collective actions such as strikes or hunger strikes of unpaid doctors abound.
} 
(Controlling for strike losses the previous year, per capita regional product, unemployment, or various other factor renders the relationship even stronger.) Public sector wage arrears also eroded trust in the state, and may have made it easier for private employers to continue delaying wages. Earle and Sabirianova (1999) argue that the institutionalization of wage arrears facilitated their spread across the economy. So there would seem to be good reason for federal policymakers to fear the accumulation of regional public sector wage arrears.

[Table 6 About Here]

And there are numerous examples of cases where the federal goverment provided emergency financial aid to pay such wages. Extracting such aid—with the help of striking workers—was a well-established game. For instance, in February 2000, just before the scheduled presidential election, the governor of Omsk, Leonid Polezhaev, traveled to Moscow to negotiate for aid to pay striking teachers, whose action had left 40,000 school children in the region without classes. He reportedly met with the finance minister and acting president Vladimir Putin. On arriving back in Omsk, Polezhaev's deputy “assured the strikers that the money necessary for paying out the teachers' salaries should arrive in the oblast in the next 10 days. ${ }^{29}$

Financial aid, when it does come, does not always go to pay the wage arrears at which it was targeted. Governors may actually have an interest in keeping some arrears. As the head of the government's social policy department, Yevgeny Gontmakher, told one newspaper: "For some governors, it is to their benefit to maintain wage arrears, in order to ask for more funds from Moscow. Aman Tuleev is an example." ${ }^{\text {’0 }}$ In December 1998, the federal Finance Ministry published a list of regions it accused of "misusing federal monies allocated for wages". ${ }^{31}$ Regions that received larger transfers and loans in 1996 or 1997 did not have lower arrears in education and healthcare in 1997. In fact, the correlation was positive. (And the same was true controlling for other revenues of the regional governments that year.)

While time series for arrears and a number of other variables would be required to test this story more rigorously, there does thus seem to be some evidence that regional governments: 1) deliberately inflate public employment, 2) use the potential militancy of health and education workers to lobby for larger federal tranfers and loans, 3) deliberately create wage arrears in these sectors to invigorate such militancy, and 4) when they get larger transfers, invest part of the proceeds in inflating public employment still further.

\footnotetext{
${ }^{29}$ Institute for East-West Studies, Russian Regional Report, 5, 7, 24 February 2000.

30 "You are talented, so find money!" Kommersant, 17 December 1999.

${ }^{31}$ Radio Free Europe/Radio Liberty, RFE/RL Newsline, Vol. 2, No. 236 Part I, 9 December 1998.
} 
If such a picture is accurate, it casts a somewhat different light on the epidemic of wage arrears in the Russian economy in the late 1990s. Such wage arrears have often been taken to be a sign of irresponsible or incompetent budgeting by the federal government. The growing public sector has been seen as the victory of inertia, socialist values, or central incompetence over liberalism. There may be some truth to this view. But a deeper explanation for the apparently irrational growth of public employment and public sector wage arrears may lie in the often dysfunctional game of federal politics as it has developed in Russia. ${ }^{32}$ An inflated regional public sector represents a reserve of hostages that can be used by regional officials to extort aid from central politicians.

A little arithmetic demonstrates that had regional governments not increased their payrolls so dramatically, the entire problem of public sector wage arrears could have been avoided. Total public sector wage arrears peaked in the third quarter of 1998 at 20.9 bn rubles. ${ }^{33}$ Between 1992 and 1998, employment in health, sport, and social protection increased by 226,000 and that in public administration grew by $1,415,000$. These additional workers, if paid at the average wage in those sectors, would have received in 1998 alone 25.1 billion rubles. Had employment in public administration and in healthcare remained at their 1992 levels, governments would have saved enough in 1998 alone to pay all existing public sector wage arrears.

\section{Conclusion}

Public employment in Russia has grown quite dramatically in the 1990s, despite the economic crisis that afflicted the country, the sharp drop in tax revenues collected, and the expectation that liberalization and privatization would lead to a smaller state. Most of this increase appears to have occurred at the regional level. The increase has been greatest where unemployment was highest and growing the fastest, in ethnically defined territorial units, and in regions which received larger federal transfers and loans. Public employment did not grow faster where regions themselves collected higher revenues. Employment in public administration grew faster during the buildup to a gubernatorial election, and slowed down afterward. It also grew much faster during the buildup to the 1996 presidential election, and slowed down afterward. Thus, regional governors appear to use public employment for several purposes: as a kind of economic insurance to cushion the population against

\footnotetext{
${ }^{32}$ For another argument that many of the roots of current problems in Russia's political economy lie in the poor state of center-region relations, see OECD (2000).

${ }^{33}$ Russian Economic Trends, 8, 4, 1999, p.109.
} 
unemployment; as a way of buying votes before elections; and, possibly, as a way of redistributing to minority ethnic groups. Their willingness to use it for any of these is conditioned by the level of federal financial aid they can attract.

By reducing the flow of regional transfers, the federal government thus might be able to slow the growth of regional public employment. But such a course is fraught with political dangers, not least because existing public employees can be provoked into strikes, as demonstrated by the unusual activism of education employees in the late 1990s. At the same time, regional governors, by diverting funds and increasing public sector wage arrears, can create reservoirs of anti-center discontent, which may show up in regional voting patterns. The paradoxical growth of public employment in Russia appears less a result of ignorant or irresolute central management than a perverse outgrowth of the competitive game of federal politics, in which elected politicians try to buy votes by protecting voters from unemployment, but simultaneously use their political clients as hostages to extract finance from the central budget. 


\section{Bibliography}

Agenor, Pierre-Richard. 1996. “The Labor Market and Economic Adjustment," IMF Staff Papers, 43, 2, pp.261335.

Alesina, Alberto, Reza Baqir and William Easterly. 1997. "Public Goods and Ethnic Divisions," NBER Working Paper 6009.

Alesina, Alberto, Nouriel Roubini and Gerald Cohen. 1997. Political Cycles and the Macroeconomy, Cambridge, MA: MIT Press.

Alesina, Alberto, Reza Baqir and William Easterly. 1998. "Redistributive Public Employment,” NBER Working Paper 6746.

Alesina, Alberto, Stephan Danninger, and Massimo Rostagno. 1999. "Redistribution Through Public Employment: The Case of Italy,” NBER, Working Paper 7387.

Beck, Nathaniel and Jonathan N. Katz. 1995. "What to Do (and Not to Do) with Time-Series-Cross-Section Data," American Political Science Review, 89, pp.634-47.

1996. "Nuisance vs. Substance: Specifying and Estimating Time-Series-

Cross-Section Models," Political Analysis, 6, pp.1-36.

Cameron, David. 1978. "The Expansion of the Public Economy: A Comparative Analysis," American Political Science Review, 72, 4, pp.1243-1261.

Cheasty, A. and J.Davis. 1996. "Fiscal Transition in Countries of the Former Soviet Union: An Interim Assessment," MOCT-MOST, No.6.

Cusack, Thomas R., Ton Notermans, and Martin Rein. 1989. "Political-Economic Aspects of Public Employment," European Journal of Political Research, 17, pp.471-500.

Gimpelson, Vladimir. 2000. "Politics of Labor Market Adjustment. The Case of Russia", in Janos Kornai, Stephan Haggard, and Robert Kaufman, Reforming the State: Fiscal and Welfare Reform in Post-Socialist Countries, New York: Cambridge University Press, forthcoming.

Freinkman, Lev and Michael Haney. 1997. "What Affects the Propensity to Subsidize: Determinants of Budget Subsidies and Transfers Financed by the Russian Regional Governments in 1992-1995," Policy Research Working Paper 1818, Washington, DC: World Bank.

Freinkman, Lev, Daniel Treisman, and Stepan Titov. 1999. Subnational Budgeting in Russia: Preempting a Potential Crisis, Washington, DC: World Bank.

Goldin, Claudia and Lawrence F. Katz. 1999. "Human Capital and Social Capital: The Rise of Secondary Schooling in America, 1910-1940,” Journal of Interdisciplinary History, 29, 4, pp.683-723.

Goskomstat RF. 1997. Sotsialnoe polozheniye i uroven zhizni naselenia Rossii, Moscow: Goskomstat RF. 1999a. Rossiisky statistichesky yezhegodnik, Moscow: Goskomstat RF.

1999b. Trud i zanyatost, Moscow: Goskomstat RF.

Heller, Peter S. and Alan A. Tait. 1984. Government Employment and Pay: Some International Comparisons, Washington, DC: IMF.

Hibbs, Douglas. 1977. "Political Parties and Macroeconomic Policy," American Political Science Review, 71, pp.1467-87. 
Kraay A. and C. Van Rijckeghem. 1995. "Employment and Wages in the Public Sector - A Cross Country Study”, IMF Working Paper, July, Washington, DC: IMF.

McFaul, Michael and Nikolai Petrov, eds. 1998. Politicheskiy Almanakh Rossii 1997, Moscow: Moscow Carnegie Center.

McFaul, Michael, Nikolai Petrov, and Andrei Ryabov. 1999. Rossia nakanune Dumskikh Vyborov 1999 goda.

Moscow: Moscow Carnegie Center.

Musgrave, Richard A. 1969. Fiscal Systems, New Haven: Yale University Press.

Nordhaus, William. 1975. "The Political Business Cycle," Review of Economic Studies, 1975, 42.

Nurnberg, B. 1999. "Transforming the Prototype: A New Administrative Order for Post-Soviet Russia?" in Nurnberg, B, The State After Communism. Administrative Transitions in Central and Eastern Europe, Washington, DC: The World Bank.

Oates, Wallace E. 1972. Fiscal Federalism, New York: Harcourt, Brace, Jovanovich. 1994. "Federalism and Government Finance," in John M. Quigley and Eugene Smolensky, eds., Modern Public Finance, Cambridge, MA: Harvard University Press, pp.126-151.

OECD. 2000. Economic Surveys: Russian Federation, Paris: OECD.

Qian, Yingyi and Gérard Roland. 1998. "Federalism and the Soft Budget Constraint," American Economic Review, December, 88, 5, pp.1143-62.

Rodrik, D. 1997. “What Drives Public Employment?” NBER Working Paper 6141, August.

Rose, Richard, ed. 1985. Public Employment in Western Nations, New York: Cambridge University Press.

Rubinfeld, Daniel. 1987. "The Economics of the Local Public Sector," in Alan Auerbach and Martin Feldstein, eds., Handbook of Public Economics, vol.2, Amsterdam: North Holland.

Russian Economic Trends. 1997. No.3.

Schiavo-Campo,S.,G. de Tommaso, A.Mukherjee. 1997a. Government Employment and Pay. A Global and Regional Perspective, Policy Research Working Paper No.1771, Washington, DC: World Bank.

Schiavo-Campo, S., G. de Tommaso, A.Mukherjee. 1997b. An International Statistical Survey of Government Employment and Pay, Policy Research Working Paper No.1806, Washington, DC: World Bank.

Shleifer, Andrei. 1998. "State versus Private Ownership,” Journal of Economic Perspectives, Vol.12, No.4.

Sinelnikov, Sergei. 1995. Byudzhetny Krizis v Rossii: 1985-1995 g., Moscow: Yevrasia.

Tabata, S. 1998. "Transfers from Federal to Regional Budgets in Russia: A Statistical Analysis," Post-Soviet Geography and Economics, Vol.39, No.8.

Tiebout, Charles. 1956. “A Pure Theory of Local Expenditures," Journal of Political Economy, 64, October, 416-24.

Treisman, Daniel. 1996."The Politics of Intergovernmental Transfers in Post-Soviet Russia," British Journal of Political Science, vol. 26, 3, July 1996, pp.299-335.

1998. "Deciphering Russia's Federal Finance: Fiscal Appeasement in 1995 and 1996," Europe-Asia Studies, Vol. 50, No.1998.

1999. After the Deluge: Regional Crises and Political Consolidation in Russia, Ann Arbor: University of Michigan Press.

Treisman, Daniel and Vladimir Gimpelson. 2000. "Political Business Cycles and Russian Elections: Or the 
Manipulations of 'Chudar'”, British Journal of Political Science, forthcoming.

Ul Haque, N., P.Montiel, and S.Sheppard. 1998. "Public Sector Efficiency and Fiscal Austerity," IMF Working Paper WP/98/56, Washington, DC: IMF.

Wagner, Adolf. 1883. Finanzwissenschaft, Third Edition, Leipzig, excerpted in Richard A. Musgrave and Alan T. Peacock, Classics in the Theory of Public Finance, London: MacMillan \& Co., 1958. 
Tables and Charts:

Table 1. Employment, by ownership, 1992-1997

(percentages, unless otherwise noted)

\begin{tabular}{|c|c|c|c|c|c|c|c|}
\hline 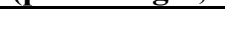 & 1992 & 1993 & 1994 & 1995 & 1996 & 1997 & 1998 \\
\hline State sector & 68.9 & 53.0 & 44.7 & 42.1 & 42.0 & 40.1 & 38.1 \\
\hline $\begin{array}{l}\text { Public } \\
\text { associations }\end{array}$ & 0.8 & 0.9 & 0.7 & 0.7 & 0.6 & 0.6 & 0.7 \\
\hline $\begin{array}{l}\text { Mixed without } \\
\text { foreign } \\
\text { participation }\end{array}$ & 10.5 & 17.6 & 21.1 & 22.2 & 21.0 & 18.3 & 16.4 \\
\hline $\begin{array}{l}\text { Foreign and } \\
\text { mixed with } \\
\text { foreign } \\
\text { participation }\end{array}$ & 0.3 & 0.4 & 0.5 & 0.6 & 0.8 & 1.1 & 1.6 \\
\hline Private sector & 19.5 & 28.1 & 33.0 & 34.4 & 35.6 & 39.9 & 43.2 \\
\hline $\begin{array}{l}\text { Total } \\
\text { Employment } \\
\text { (millions) }\end{array}$ & $\begin{array}{c}100 \\
(72.1)\end{array}$ & $\begin{array}{c}100 \\
(70.9)\end{array}$ & $\begin{array}{c}100 \\
(68.5)\end{array}$ & $\begin{array}{c}100 \\
(66.4)\end{array}$ & $\begin{array}{c}100 \\
(66.0)\end{array}$ & $\begin{array}{c}100 \\
(64.6)\end{array}$ & $\begin{array}{c}100 \\
(63.6)\end{array}$ \\
\hline
\end{tabular}

Source: Goskomstat Rossii, Rossiisky Statistichesky Yezhegodnik 1999, p.114. 


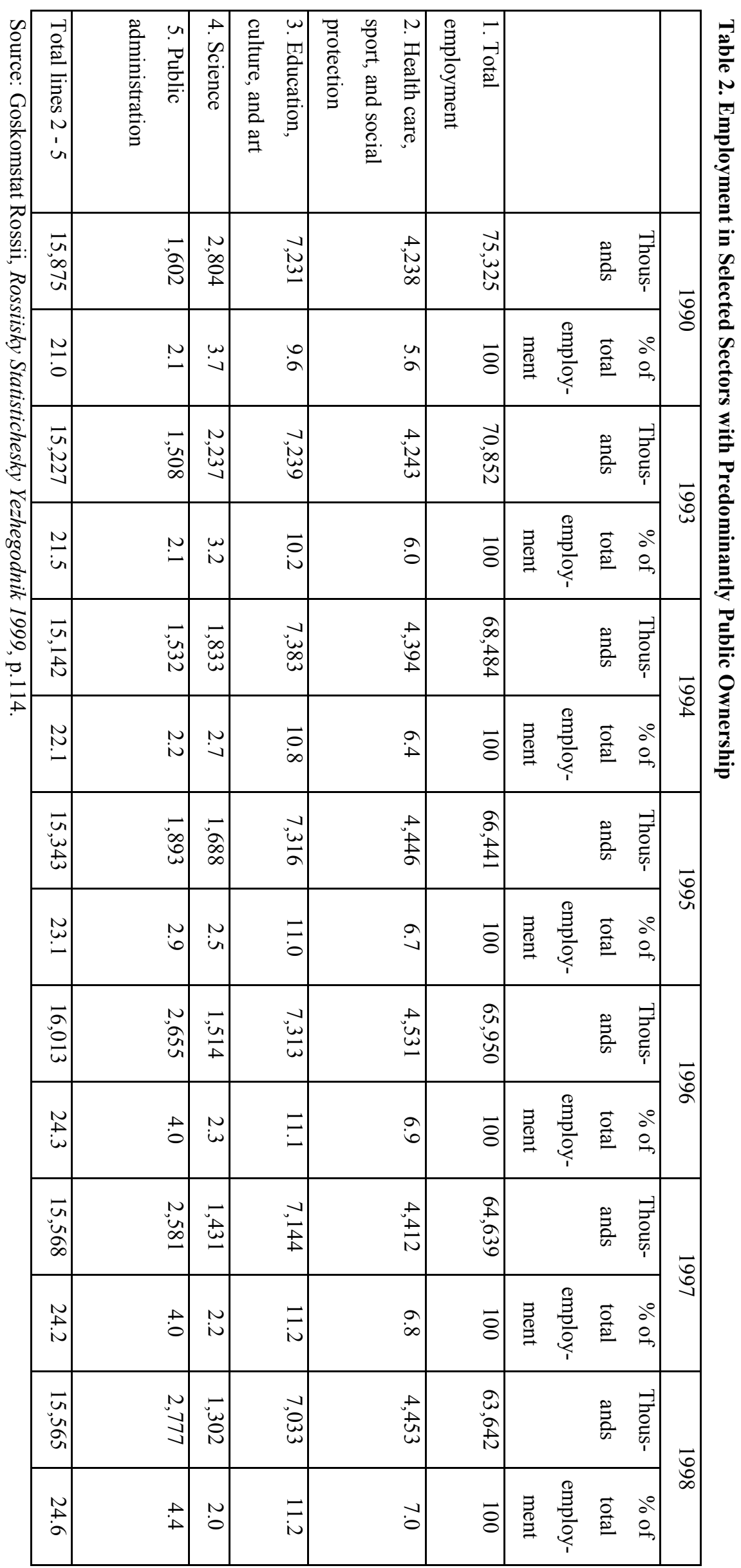




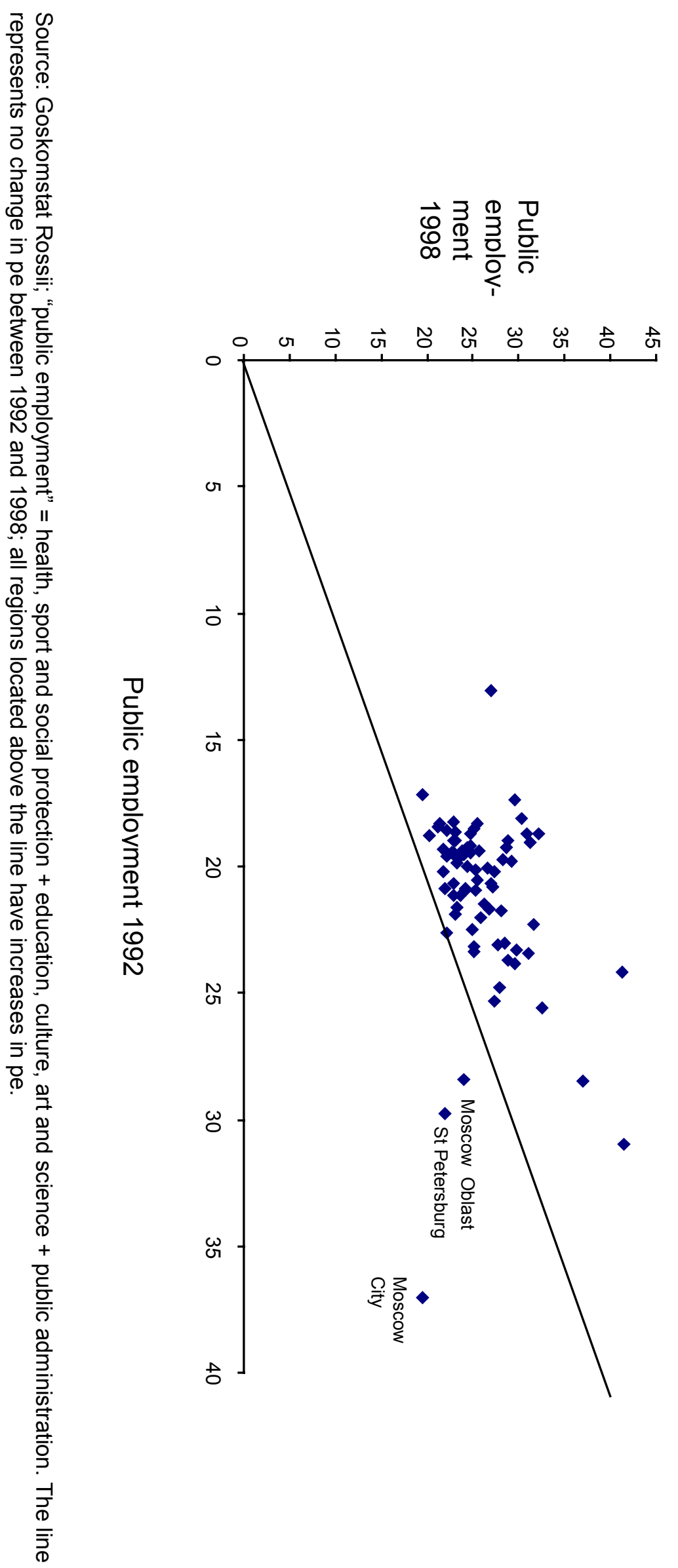

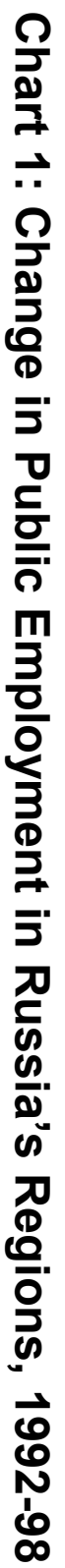


Table 3. Employment in Public Sectors, Descriptive Statistics, 1992-1998.

\begin{tabular}{|l|l|l|l|l|}
\hline Variable & $\begin{array}{l}\text { Mean } \\
\text { (unweighted) }\end{array}$ & $\begin{array}{l}\text { Standard } \\
\text { Deviation }\end{array}$ & Minimum & Maximum \\
\hline PE $_{92}$ & 21.09 & 3.40 & 13.09 & 37.05 \\
\hline PE $_{93}$ & 21.38 & 3.35 & 14.53 & 34.17 \\
\hline PE $_{94}$ & 22.77 & 3.01 & 15.83 & 33.92 \\
\hline PE $_{95}$ & 24.27 & 3.09 & 17.84 & 34.87 \\
\hline PE $_{96}$ & 25.79 & 3.33 & 17.85 & 41.17 \\
\hline PE $_{97}$ & 25.55 & 3.73 & 19.11 & 40.28 \\
\hline PE $_{98}$ & 26.28 & 5.21 & 19.50 & 54.04 \\
\hline
\end{tabular}


Table 4. What Explains Higher Regional Public Employment?

(Dependent variable is share of predominantly public sectors ${ }^{1}$ in total employment; OLS with panelcorrected standard errors)

\begin{tabular}{|c|c|c|c|c|c|c|c|c|c|}
\hline & (1) & (2) & (3) & (4) & (5) & (6) & (7) & (8) & (9) \\
\hline \multicolumn{10}{|l|}{ Economic Development } \\
\hline $\begin{array}{l}\text { Gross regional product per } \\
\text { capita }\end{array}$ & $\begin{array}{l}-.14 * * * \\
(.05)\end{array}$ & & & & & & & & $\begin{array}{l}-.08 \\
(.05)\end{array}$ \\
\hline Urbanization & & $\begin{array}{l}-.03 * * * \\
(.01)\end{array}$ & & & & & & & \\
\hline \multicolumn{10}{|l|}{ Redistribution to Minorities } \\
\hline Ethnic status & & & $\begin{array}{l}.84 * * * \\
(.18)\end{array}$ & & & & & & $\begin{array}{l}.29 * \\
(.15)\end{array}$ \\
\hline \multicolumn{10}{|l|}{ Electoral Cycle } \\
\hline $\begin{array}{l}\text { Year before (expected) } \\
\text { gubernatorial election }\end{array}$ & & & & $\begin{array}{l}.39 \\
(.25)\end{array}$ & $\begin{array}{l}.40 \\
(.25)\end{array}$ & & & & $\begin{array}{l}.01 \\
(.16)\end{array}$ \\
\hline Year of (expected) & & & & $.61 * *$ & $.62 * *$ & & & & -.14 \\
\hline gubernatorial election & & & & $(.26)$ & $(.26)$ & & & & $(.18)$ \\
\hline Year after gubernatorial & & & & -.04 & .10 & & & & .02 \\
\hline election & & & & $(.22)$ & $(.30)$ & & & & $(.20)$ \\
\hline $\begin{array}{l}\text { New governor elected } \\
\text { previous year }\end{array}$ & & & & & $\begin{array}{l}-.24 \\
(.35)\end{array}$ & & & & $\begin{array}{l}-.27 \\
(.23)\end{array}$ \\
\hline $\begin{array}{l}\text { Governor Ideology } \\
\text { (At least part of year) } \\
\text { governor affiliated with } \\
\text { communists }\end{array}$ & & & & & & $\begin{array}{l}-.06 \\
(.21)\end{array}$ & & & $\begin{array}{l}.06 \\
(.15)\end{array}$ \\
\hline \multicolumn{10}{|l|}{ Economic Insurance } \\
\hline $\begin{array}{l}\text { Previous year } \\
\text { unemployment } \\
\text { Change in } \\
\text { unemployment }\end{array}$ & & & & & & & $\begin{array}{l}.08 * * * \\
(.02) \\
.19 * * * \\
(.02)\end{array}$ & & $\begin{array}{l}.02 \\
(.02) \\
.09 * * * \\
(.02)\end{array}$ \\
\hline \multicolumn{10}{|l|}{ Government Budget } \\
\hline $\begin{array}{l}\text { Previous year federal } \\
\text { transfers and loans } \\
\text { Change in federal transfers } \\
\text { and loans }\end{array}$ & & & & & & & & $\begin{array}{l}.72 * * * \\
(.11) \\
.62 * * * \\
(.20)\end{array}$ & $\begin{array}{l}.73 * * * \\
(.13) \\
.61 * * * \\
(.19)\end{array}$ \\
\hline \multicolumn{10}{|l|}{ Controls } \\
\hline $\begin{array}{l}\text { Percent of population under } \\
16 \\
\text { Percent of population } \\
\text { over } 55 \\
\text { Capital city }\end{array}$ & & & & & & & & & $\begin{array}{l}-.02 \\
(.03) \\
-.02 \\
(.03) \\
-.65^{*} \\
(.39)\end{array}$ \\
\hline $\begin{array}{l}\text { Previous year public } \\
\text { employment }\end{array}$ & $\begin{array}{l}.98 * * * \\
(.02)\end{array}$ & $\begin{array}{l}.93 * * * \\
(.02)\end{array}$ & $\begin{array}{l}.95 * * * \\
(.02)\end{array}$ & $\begin{array}{l}.92 * * * \\
(.02)\end{array}$ & $\begin{array}{l}.91 * * * \\
(.02)\end{array}$ & $\begin{array}{l}.99 * * * \\
(.02)\end{array}$ & $\begin{array}{l}.99 * * * \\
(.02)\end{array}$ & $\begin{array}{l}.99 * * * \\
(.02)\end{array}$ & $\begin{array}{l}.91 * * * \\
(.02)\end{array}$ \\
\hline 1994 & $\begin{array}{l}1.10^{* * * *} \\
(.26)\end{array}$ & $\begin{array}{l}1.12 * * * \\
(.22)\end{array}$ & $\begin{array}{l}1.11^{* * *} \\
(.26)\end{array}$ & $\begin{array}{l}.73 * * * \\
(.18)\end{array}$ & $\begin{array}{l}1.07 * * * \\
(.16)\end{array}$ & $\begin{array}{l}1.09 * * * \\
(.26)\end{array}$ & $\begin{array}{l}1.09^{* * * *} \\
(.26)\end{array}$ & $\begin{array}{l}1.10^{* * * *} \\
(.26)\end{array}$ & $\begin{array}{l}.92 * * * \\
(.16)\end{array}$ \\
\hline 1995 & $\begin{array}{l}1.16^{* * * *} \\
(.26)\end{array}$ & $\begin{array}{l}1.25^{* * * *} \\
(.23)\end{array}$ & $\begin{array}{l}1.22 * * * \\
(.26)\end{array}$ & $\begin{array}{l}.76^{* * * *} \\
(.18)\end{array}$ & $\begin{array}{l}1.37 * * * \\
(.17)\end{array}$ & $\begin{array}{l}.95 * * * \\
(.29)\end{array}$ & $\begin{array}{l}.95 * * * \\
(.29)\end{array}$ & $\begin{array}{l}1.16^{* * *} \\
(.27)\end{array}$ & $\begin{array}{l}1.17 * * * \\
(.21)\end{array}$ \\
\hline 1996 & $\begin{array}{l}1.29 * * * \\
(.27)\end{array}$ & $\begin{array}{l}1.46^{* * * *} \\
(.23)\end{array}$ & $\begin{array}{l}1.39 * * * \\
(.27)\end{array}$ & $\begin{array}{l}1.12 * * * \\
(.19)\end{array}$ & $\begin{array}{l}1.59 * * * \\
(.17)\end{array}$ & $\begin{array}{l}.95 * * * \\
(.31)\end{array}$ & $\begin{array}{l}.93 * * * \\
(.31)\end{array}$ & $\begin{array}{l}1.28 * * * \\
(.28)\end{array}$ & $\begin{array}{l}1.64 * * * \\
(.23)\end{array}$ \\
\hline 1997 & $\begin{array}{l}-.45 \\
(.28)\end{array}$ & $\begin{array}{l}-.34 \\
(.24)\end{array}$ & $\begin{array}{l}-.29 \\
(.28)\end{array}$ & $\begin{array}{l}-.94 * * * \\
(.21)\end{array}$ & $\begin{array}{l}-.23 \\
(.18)\end{array}$ & $\begin{array}{l}-.55^{*} \\
(.30)\end{array}$ & $\begin{array}{l}-.55^{*} \\
(.30)\end{array}$ & $\begin{array}{l}-.47 \\
(.30)\end{array}$ & $\begin{array}{l}-.35 \\
(.24)\end{array}$ \\
\hline 1998 & $\begin{array}{l}.51 * \\
(.28)\end{array}$ & $\begin{array}{l}.55^{* *} \\
(.24)\end{array}$ & $\begin{array}{l}.67 * * \\
(.28)\end{array}$ & no data & no data & $\begin{array}{l}.42 \\
(.28)\end{array}$ & $\begin{array}{l}.42 \\
(.28)\end{array}$ & $\begin{array}{l}.50 * \\
(.29)\end{array}$ & no data \\
\hline Constant & $\begin{array}{l}1.17 * * \\
(.56)\end{array}$ & $\begin{array}{l}3.98 * * * \\
(.61)\end{array}$ & $\begin{array}{l}1.18^{* *} \\
(.53)\end{array}$ & $\begin{array}{l}1.50 * * * \\
(.38)\end{array}$ & $\begin{array}{l}1.85 * * * \\
(.36)\end{array}$ & $\begin{array}{l}.54 \\
(.52)\end{array}$ & $\begin{array}{l}.58 \\
(.52)\end{array}$ & $\begin{array}{l}.52 \\
(.54)\end{array}$ & $\begin{array}{l}2.94 * * \\
(1.34)\end{array}$ \\
\hline $\mathbf{N}$ & 471 & 468 & 471 & 390 & 390 & 471 & 471 & 471 & 388 \\
\hline Wald Chi Square & 2451 & 2963 & 2526 & 4174 & 4467 & 2442 & 2445 & 2395 & 5156 \\
\hline Pr $>$ Chi Square & .000 & .000 & .000 & .000 & .000 & .000 & .000 & .000 & .000 \\
\hline
\end{tabular}

Panel-corrected standard errors in parentheses. $* \mathrm{p}<.10, * * \mathrm{p}<.05, * * * \mathrm{p}<.01$.

Note: 1998 data were unavailable for transfers and loans or for unemployment. Data from 1993-98.

${ }^{1}$ healthcare, sport and social protection; education, culture, art and science; and public administration. 
Table 5. Explaining Employment in Particular Predominantly

Public Sectors (OLS with panel-corrected standard errors)

\begin{tabular}{|c|c|c|c|}
\hline & $\begin{array}{l}\text { Share of Health, } \\
\text { Sport, and Social } \\
\text { Protection in Total } \\
\text { Regional } \\
\text { Employment }\end{array}$ & $\begin{array}{l}\text { Share of } \\
\text { Education, } \\
\text { Culture, Art and } \\
\text { Science in Total } \\
\text { Regional } \\
\text { Employment } \\
\end{array}$ & $\begin{array}{l}\text { Share of Public } \\
\text { Administration in } \\
\text { Total Regional } \\
\text { Employment }\end{array}$ \\
\hline \multicolumn{4}{|l|}{ Economic Development } \\
\hline $\begin{array}{l}\text { Gross regional product } \\
\text { per capita }\end{array}$ & $\begin{array}{l}-.03 \\
(.02)\end{array}$ & $\begin{array}{l}-.025 \\
(.032)\end{array}$ & $\begin{array}{l}-.033 \\
(.021)\end{array}$ \\
\hline \multicolumn{4}{|l|}{$\begin{array}{l}\text { Redistribution to } \\
\text { Minorities }\end{array}$} \\
\hline Ethnic status & $\begin{array}{l}.080 \\
(.051)\end{array}$ & $\begin{array}{l}.252 * * \\
(.102)\end{array}$ & $\begin{array}{l}.001 \\
(.063)\end{array}$ \\
\hline \multicolumn{4}{|l|}{ Electoral Cycle } \\
\hline $\begin{array}{l}\text { Year before (expected) } \\
\text { gubernatorial election } \\
\text { Year of (expected) } \\
\text { gubernatorial election } \\
\text { Year after gubernatorial } \\
\text { election } \\
\text { New governor elected } \\
\text { previous year }\end{array}$ & $\begin{array}{l}.011 \\
(.053) \\
-.052 \\
(.061) \\
.057 \\
(.067) \\
-.103 \\
(.078)\end{array}$ & $\begin{array}{l}-.127 \\
(.103) \\
-.050 \\
(.119) \\
.200 \\
(.131) \\
-.315^{* *} \\
(.153)\end{array}$ & $\begin{array}{l}.120 * \\
(.065) \\
-.056 \\
(.076) \\
-.249 * * * \\
(.084) \\
.135 \\
(.096)\end{array}$ \\
\hline \multicolumn{4}{|l|}{ Governor Ideology } \\
\hline $\begin{array}{l}\text { (At least part of year) } \\
\text { governor affiliated with } \\
\text { communists }\end{array}$ & $\begin{array}{l}-.015 \\
(.049)\end{array}$ & $\begin{array}{l}.060 \\
(.097)\end{array}$ & $\begin{array}{l}-.013 \\
(.061)\end{array}$ \\
\hline $\begin{array}{l}\text { Economic Insurance } \\
\text { Previous year } \\
\text { unemployment } \\
\text { Change in } \\
\text { unemployment }\end{array}$ & $\begin{array}{l}.009 \\
(.007) \\
.036 * * * \\
(.008)\end{array}$ & $\begin{array}{l}-.006 \\
(.014) \\
.043 * * * \\
(.016)\end{array}$ & $\begin{array}{l}.018^{*} \\
(.009) \\
.013 \\
(.010)\end{array}$ \\
\hline \multicolumn{4}{|l|}{ Government Budget } \\
\hline $\begin{array}{l}\text { Previous year federal } \\
\text { transfers and loans } \\
\text { Change in federal } \\
\text { transfers and loans }\end{array}$ & $\begin{array}{l}.124 * * * \\
(.045) \\
.036 \\
(.063)\end{array}$ & $\begin{array}{l}.419 * * * \\
(.087) \\
.557 * * * \\
(.123)\end{array}$ & $\begin{array}{l}.173 * * * \\
(.057) \\
-.014 \\
(.079)\end{array}$ \\
\hline \multicolumn{4}{|l|}{ Controls } \\
\hline $\begin{array}{l}\text { Percent of population } \\
\text { under } 16\end{array}$ & $\begin{array}{l}-.022 * * \\
(.010)\end{array}$ & $\begin{array}{l}.047 * * \\
(.021)\end{array}$ & $\begin{array}{l}-.034 * * * \\
(.013)\end{array}$ \\
\hline $\begin{array}{l}\text { Percent of population } \\
\text { over } 55\end{array}$ & $\begin{array}{l}-.006 \\
(.009)\end{array}$ & $\begin{array}{l}.018 \\
(.017)\end{array}$ & $\begin{array}{l}-.031 * * * \\
(.011)\end{array}$ \\
\hline Capital city & $\begin{array}{l}-.207^{*} \\
(.108)\end{array}$ & $\begin{array}{l}.381 \\
(.290)\end{array}$ & $\begin{array}{l}-.340 * * \\
(.133)\end{array}$ \\
\hline $\begin{array}{l}\text { Previous year public } \\
\text { employment in this sector }\end{array}$ & $\begin{array}{l}.879 * * * \\
(.025)\end{array}$ & $\begin{array}{l}.861 * * * \\
(.020)\end{array}$ & $\begin{array}{l}.942 * * * \\
(.028)\end{array}$ \\
\hline 1994 & $\begin{array}{l}.315 * * * \\
(.054)\end{array}$ & $\begin{array}{l}.642 * * * \\
(.105)\end{array}$ & $\begin{array}{l}-.044 \\
(.067)\end{array}$ \\
\hline 1995 & $\begin{array}{l}.188 * * * \\
(.069)\end{array}$ & $\begin{array}{l}649 * * * \\
(.133)\end{array}$ & $\begin{array}{l}.365^{* * * *} \\
(.084)\end{array}$ \\
\hline 1996 & $\begin{array}{l}.165^{* * *} \\
(.077)\end{array}$ & $\begin{array}{l}310 * * \\
(.149)\end{array}$ & $\begin{array}{l}1.192 * * * \\
(.095)\end{array}$ \\
\hline 1997 & $\begin{array}{l}-.113 \\
(.080)\end{array}$ & $\begin{array}{l}.169 \\
(.152)\end{array}$ & $\begin{array}{l}-.412 * * * \\
(.109)\end{array}$ \\
\hline 1998 & no data & no data & no data \\
\hline Constant & $\begin{array}{l}1.514 * * * \\
(.464)\end{array}$ & $\begin{array}{l}.032 \\
(.839)\end{array}$ & $\begin{array}{l}1.761 * * * \\
(.543)\end{array}$ \\
\hline $\mathbf{N}$ & 388 & 385 & 388 \\
\hline Wald Chi Square & 2733 & 5155 & 4237 \\
\hline Pr $>$ Chi Square & .000 & .000 & .000 \\
\hline
\end{tabular}

Note: 1998 data were unavailable for transfers and loans or for unemployment. Data from 1993-98. 
Table 6. Strikes in Education and Healthcare

\begin{tabular}{|c|c|c|c|c|c|c|c|c|}
\hline & \multicolumn{4}{|l|}{ Education } & \multicolumn{4}{|l|}{ Healthcare } \\
\hline & $\begin{array}{l}\text { organizations } \\
\text { in which } \\
\text { strikes took } \\
\text { place }\end{array}$ & $\begin{array}{l}\text { share } \\
\text { of } \\
\text { total } \\
(\%)\end{array}$ & $\begin{array}{l}\text { thousand } \\
\text { man-days } \\
\text { lost to strikes }\end{array}$ & $\begin{array}{l}\text { share } \\
\text { of } \\
\text { total } \\
(\%)\end{array}$ & $\begin{array}{l}\text { organizations } \\
\text { in which } \\
\text { strikes took } \\
\text { place }\end{array}$ & $\begin{array}{l}\text { share } \\
\text { of } \\
\text { total } \\
(\%)\end{array}$ & $\begin{array}{l}\text { thousand } \\
\text { man-days } \\
\text { lost to strikes }\end{array}$ & $\begin{array}{l}\text { share } \\
\text { of } \\
\text { total } \\
(\%)\end{array}$ \\
\hline 1992 & 4929 & 79 & 1217.5 & 64 & 943 & 15 & 292.9 & 15 \\
\hline 1993 & 0 & 0 & 0 & 0 & 1 & 0 & .1 & 0 \\
\hline 1994 & 279 & 54 & 165.0 & 22 & 0 & 0 & 0 & 0 \\
\hline 1995 & 8555 & 97 & 611.7 & 45 & 5 & 0 & 2.3 & 0 \\
\hline 1996 & 7396 & 89 & 1488.6 & 37 & 229 & 3 & 162.8 & 4 \\
\hline 1997 & 15610 & 92 & 3504.8 & 58 & 712 & 4 & 372.4 & 6 \\
\hline 1998 & 10586 & 95 & 1890.4 & 66 & 143 & 1 & 62.2 & 2 \\
\hline
\end{tabular}

Source: Trud I Zanyatost v Rossii 1999, p.224 


\section{IZA Discussion Papers}

No. Author(s)

61

62

R. Winkelmann

A. Thalmaier

63

M. Ward

64

M. Ward

65

H. Lehmann

J. Wadsworth

A. Acquisti

66

E. J. Bird

H. Kayser

J. R. Frick

G. G. Wagner

67 R. T. Riphahn

A. Thalmaier

68

B. Dietz

69

M.-S. Yun

70

I. N. Gang

F.L. Rivera-Batiz

71 L. Goerke

72 J. Fersterer

R. Winter-Ebmer

73 G. S. Epstein

S. Nitzan

74 M. Kräkel

75 B. Henry

M. Karanassou

D. J. Snower

76 G. Brunello

M. Giannini

77
Title

Immigration: The New Zealand Experience

Bestimmungsgründe von Fehlzeiten: Welche

Rolle spielt die Arbeitslosigkeit?

Your Everyday, Average Academic

Salary and the Gender Salary Gap in the

Academic Profession

Grime and Punishment: Job Insecurity and Wage

Arrears in the Russian Federation

The Immigrant Welfare Effect: Take-Up or

Eligibility?

Behavioral Effects of Probation Periods:

An Analysis of Worker Absenteeism

Ethnic German Immigration from Eastern Europe and the former Soviet Union to Germany: the Effects of Migrant Networks

Generalized Selection Bias and the Decomposition 6 of Wage Differentials

Immigrants and Unemployment in the European 1

Community

The Wedge

Are Austrian Returns to Education Falling Over

Time?

The Endogenous Determination of Minimum Wage 3

Strategic Mismatches in Competing Teams

Adjustment Dynamics and the Natural Rate: An 1

Account of UK Unemployment

Selective Schools

Knowing What Works: The Case for Rigorous

Program Evaluation
3

5

5

6

Area Date

1

10/99

10/99

10/99

$10 / 99$

10/99

10/99

10/99

$11 / 99$

$11 / 99$

$11 / 99$

$11 / 99$

$11 / 99$

$11 / 99$

$12 / 99$

$12 / 99$

12/99

12/99 
Entrepreneurship from Scratch: Lessons on the

Transition Economies

80 J. C. van Ours

J. Veenman

81 T. J. Hatton

S. Wheatley Price

82 K. A. Konrad

83 R. Euwals

The Netherlands: Old Emigrants - Young

Privacy, time consistent optimal labor income 
M. Rosholm

N. Smith

An Extension of Mortensen and Pissarides (1994)

Ownership or Performance: What Determines

Job Tenure of Two Cohorts of Young German Men 1979 - 1990: An analysis of the (West-)German

Employment Statistic Register Sample concerning multivariate failure times and unobserved heterogeneity

107 J. C. van Ours

Fast Track or Failure: A Study of the Completion 

115 A. Cigno
F. C. Rosati
116 C. Belzil

A. Haas

C. Klose

118 M. A. Shields

M. E. Ward

119 A. Lindbeck

D. J. Snower

120 P. T. Pereira

P. S. Martins

121 J. C. van Ours
117 S. Bender

Why do Indian Children Work, and is it Bad for

3 Them?

Unemployment Insurance and Subsequent Job

Duration: Job Matching vs. Unobserved

Heterogeneity

IAB Employment Subsample 1975-1995.

Opportunities for Analysis Provided by the

Anonymised Subsample

Improving Nurse Retention in the British National Health Service: The Impact of Job Satisfaction on Intentions to Quit

The Division of Labor and the Market for

Organizations

Does Education Reduce Wage Inequality?

Quantile Regressions Evidence from Fifteen

European Countries

Do Active Labor Market Policies Help Unemployed $\quad 4 / 6$ Workers to Find and Keep Regular Jobs?

Returns to Human Capital under the Communist

Wage Grid and During the Transition to a Market

J. Svejnar

K. Terrell

123 J. Hunt

124 R. T. Riphahn

125 F. Büchel

J. R. Frick

126 J. Fersterer

R. Winter-Ebmer

127 M. Karanassou

D. J. Snower

128

O. Ashenfelter

D. Ashmore

O. Deschênes

129 B. R. Chiswick

M. E. Hurst

130 G. Brunello

S. Comi

C. Lucifora

131 B. R. Chiswick
Economy

Why Do People Still Live in East Germany? 1

$3 / 00$

Rational Poverty or Poor Rationality? The Take-up 3

$3 / 00$

of Social Assistance Benefits

The Income Portfolio of Immigrants in Germany - $\quad 1 / 3 \quad 3 / 00$

Effects of Ethnic Origin and Assimilation. Or:

Who Gains from Income Re-Distribution?

Smoking, Discount Rates, and Returns to

Education

Chain Reaction Approach

Do Unemployment Insurance Recipients Actively

Seek Work? Evidence From Randomized Trials in

Four U.S. States

The Employment, Unemployment and

Unemployment Compensation Benefits of Immigrants

$5 \quad 3 / 00$

3

$3 / 00$

6

$3 / 00$

The Returns to Education in Italy: A New Look at

the Evidence

$1 / 3$

$3 / 00$

Are Immigrants Favorably Self-Selected? An

Economic Analysis
Characteristics of Unemployment Dynamics: The 
Hours and Wages in the Depression: British Engineering, 1926-1938

133 D. N. F. Bell

R. A. Hart

O. Hübler

W. Schwerdt

134 A. D. Kugler

G. Saint-Paul

135 A. Barrett

P. J. O'Connell

136 M. Bräuninger

M. Pannenberg

137 J.-St. Pischke

138 J. Zweimüller

R. Winter-Ebmer

139 R. A. Hart

Y. Ma

140 G. Brunello

S. Comi

141 R. Hujer

M. Wellner

142 J. J. Dolado

F. Felgueroso

J. F. Jimeno

143 P. J. Luke

M. E. Schaffer

144 G. Saint-Paul

145 M.-S. Yun

146 T. K. Bauer

J. P. Haisken-DeNew

147 M. Belot

J. C. van Ours

148 L. Goerke

149 R. Lalive

J. C. van Ours

J. Zweimüller
Paid and Unpaid Overtime Working in Germany and 1 the UK

$3 / 00$

Hiring and Firing Costs, Adverse Selection and

3

$3 / 00$

Long-term Unemployment

Is There a Wage Premium for Returning Irish

1

$3 / 00$

Migrants?

Unemployment and Productivity Growth: An

3

$3 / 00$

Empirical Analysis within the Augmented Solow

Model

Continuous Training in Germany

$3 / 00$

Firm-specific Training: Consequences for Job

$3 / 00$

Mobility

Wages, Hours and Human Capital over the

Life Cycle

Education and Earnings Growth: Evidence from $11 \quad 2 / 5 \quad 4 / 00$

European Countries

The Effects of Public Sector Sponsored Training on

Individual Employment Performance in East

Germany

Explaining Youth Labor Market Problems in Spain: 3

Crowding-Out, Institutions, or Technology Shifts?

$4 / 00$

Wage Determination in Russia: An Econometric 4

Investigation

Flexibility vs. Rigidity: Does Spain have the worst of 1 both Worlds?

Decomposition Analysis for a Binary Choice Model

Employer Learning and the Returns to Schooling

Does the Recent Success of Some OECD

Countries in Lowering their Unemployment Rates

Lie in the Clever Design of their Labour Market

Reforms?

Employment Effects of Labour Taxation in an Efficiency Wage Model with Alternative Budget Constraints and Time Horizons

The Impact of Active Labor Market Programs and Benefit Entitlement Rules on the Duration of Unemployment
7

$4 / 00$

5

$4 / 00$

$4 / 00$

$4 / 00$

$3 \quad 4 / 00$

3

$5 / 00$

$3 / 6 \quad 5 / 00$ 
J.-St Pischke

151 M. Ward

152 J. J. Dolado

F. Felgueroso

J. F. Jimeno

153 A. S. Kalwij

M. Gregory

154 Michael Gerfin Michael Lechner

155

J. Hansen

156

A. Björklund

T. Eriksson

M. Jäntti

O. Raaum

E. Österbacka

159 P.- J. Jost

M. Kräkel

160 M. Lofstrom

161
V. Gimpelson
D. Treisman
G. Monusova

Gender, Salary and Promotion in the Academic 5 Profession

The Role of the Minimum Wage in the Welfare 3

State: An Appraisal

Overtime Hours in Great Britain over the Period 3

$5 / 00$

1975-1999: A Panel Data Analysis

Microeconometric Evaluation of the Active Labour 6 Market Policy in Switzerland

The Duration of Immigrants' Unemployment Spells: $\quad 1 / 3$ Evidence from Sweden

Language Proficiency and Labour Market Per- 1 formance of Immigrants in the UK

Household Production, Full Consumption and $\quad 7$ the Costs of Children

Brother Correlations in Earnings in Denmark, 5 Finland, Norway and Sweden Compared to the United States

Preemptive Behavior in Sequential Tournaments

A Comparison of the Human Capital and Signaling Models: The Case of the Self-Employed and the Increase in the Schooling Premium in the 1980's

Public Employment and Redistributive Politics:

4 $6 / 00$

Evidence from Russia's Regions 